\title{
Static mass-balance sensitivity of Arctic glaciers and ice caps using a degree-day approach
}

\author{
Mattias DE WOUL, Regine HOCK \\ Department of Physical Geography and Quaternary Geology, Stockholm University SE-106 91 Stockholm, Sweden \\ E-mail: mattias.dewoul@natgeo.su.se
}

\begin{abstract}
Future climate warming is predicted to be more pronounced in the Arctic where approximately two-thirds of all small glaciers on Earth are located. A simple mass-balance model was applied to 42 glaciers and ice caps north of $60^{\circ} \mathrm{N}$ to estimate mass-balance sensitivities to a hypothetical climate perturbation. The model is based on daily temperature and precipitation data from climate stations in the vicinity of each glacier and ice cap. A regression analysis was made using a degree-day approach where the annual sum of positive daily air temperatures was correlated to measured summer mass balance, and the total annual snow precipitation was correlated to measured winter mass balance. The net mass-balance sensitivity to a hypothetical temperature increase of $+1 \mathrm{~K}$ ranged from -0.2 to $-2.0 \mathrm{~m} \mathrm{a}^{-1}$, and an assumed increase in precipitation of $+10 \%$ changed the mass balance by $<+0.1$ to $+0.4 \mathrm{~m} \mathrm{a}^{-1}$, thus on average offsetting the effect of a temperature increase by approximately $20 \%$. Maritime glaciers showed considerably higher mass-balance sensitivities than continental glaciers, in agreement with similar previous studies. The highest sensitivities were found in Iceland, exceeding those reported in previous studies. Extrapolating our results, glaciers and ice caps north of $60^{\circ} \mathrm{N}$ are estimated to contribute $\sim 0.6 \mathrm{~mm} \mathrm{a}^{-1} \mathrm{~K}^{-1}$ to global sea-level rise. Our results highlight the value of long-term massbalance records and meteorological records in remote areas.
\end{abstract}

\section{INTRODUCTION}

Small glaciers and ice caps are very sensitive to climate changes, and even though they only cover 3\% of the Earth's total glacierized land area, studies have shown that they have contributed $\sim 20 \%$ to the observed sea-level rise during the last century (Church and others, 2001; Arendt and others, 2002). Glaciers north of $60^{\circ} \mathrm{N}$ constitute a significant part of the area and volume of the world's small glaciers and ice caps, covering an area of $\sim 275000 \mathrm{~km}^{2}$ (Dowdeswell and others, 1997). Future climate warming has been predicted to be more pronounced in the Arctic than at lower latitudes (Dowdeswell and Hagen, 2004), but the response of glaciers to potential future climate change has only been studied for a very limited number of Arctic glaciers and ice caps. The definition of the Arctic varies widely among authors and disciplines (Przybylak, 2003). Following ACIA (2005) we refer to the area north of $60^{\circ} \mathrm{N}$, although this area includes both real Arctic continental glaciers and maritime non-Arctic glaciers in terms of different climatic environments.

Mass-balance records of varying lengths exist for more than 40 Arctic glaciers and ice caps, with the earliest beginning in the 1940s (Dowdeswell and others, 1997), but few include $>20$ years (Dyurgerov and Meier, 1997). Most Arctic glaciers and ice caps have experienced significant negative mass-balance trends during the last 40 years, although these are not uniform across the Arctic (Dowdeswell and others, 1997). Alaskan glaciers have extensively thinned during recent decades (Arendt and others, 2002), while many glaciers in Iceland and Scandinavia experienced positive mass balances in the 1990s, possibly explained by internal variations in the climate system, such as increasing precipitation due to changes in atmospheric circulation (Reichert and others, 2001).

The response of glaciers to climate change is often expressed in terms of static or dynamic mass-balance sensitivities. In contrast to the dynamic sensitivity, the static sensitivity neglects changes in glacier size and geometry, mass-balance height feedback and imbalance, and only refers to the change in area-weighted average mass balance caused by an instant change in a climatic parameter, in this case temperature or precipitation. Jóhannesson (1997) found that the difference between the static and the dynamic approach was negligible for small climate perturbations applied to smaller ice masses close to equilibrium over the next 100 years, but significant beyond that timescale. For relatively large ice masses and rapidly retreating glaciers, the difference becomes significant after a few decades, and by 2100 the dynamic mass-balance sensitivity is about twothirds of the static mass-balance sensitivity (Oerlemans and others, 1998).

Previous studies have employed a large range of models of varying complexity including simple temperature-index (e.g. Braithwaite and Zhang, 1999), energy-balance (e.g. Oerlemans, 1992) and ice-dynamic models (e.g. Schneeberger and others, 2001), in order to assess the response of glaciers to climate change. Sophisticated approaches are important for developing models and understanding processes, but they are not always practical for understanding how glaciers react on a global scale, due to lack of the input data necessary to widely apply such models. Hence, simple models with restricted data requirements are necessary to allow a large number of glaciers to be assessed.

While many studies have focused on one glacier or a small number of glaciers, few studies have addressed the issue of mass-balance sensitivity for a larger number of glaciers, and to our knowledge only one (Oerlemans and others, 2005) has explicitly focused on the Arctic. A summary of studies including high-latitude glaciers, among others, is given in Table 1. Static mass-balance sensitivities to an increase in temperature generally range from -0.1 to $-1.35 \mathrm{~m} \mathrm{a}^{-1} \mathrm{~K}^{-1}$ (Table 1). Most studies conclude that glaciers 
Table 1. Previous studies reporting static mass-balance sensitivities of at least two glaciers north of $60^{\circ} \mathrm{N}$, that used energy-balance (EB) or temperature-index $(\mathrm{TI})$ melt models

\begin{tabular}{|c|c|c|c|c|}
\hline Glaciers & Method & $\begin{array}{l}\text { Static mass-balance } \\
\text { sensitivity to } T+1 \mathrm{~K} \\
\mathrm{~m} \mathrm{a}^{-1}\end{array}$ & $\begin{array}{l}\text { Static mass-balance } \\
\text { sensitivity to } P+10 \% \\
\qquad \mathrm{~m} \mathrm{a}^{-1}\end{array}$ & Source \\
\hline
\end{tabular}

\begin{tabular}{|c|c|c|c|c|}
\hline 12 glaciers & $\mathrm{EB}$ & -0.12 to -1.15 & & $\begin{array}{l}\text { Oerlemans and } \\
\text { Fortuin (1992) }\end{array}$ \\
\hline 12 glaciers & $\mathrm{TI}, \mathrm{EB}$ & -0.4 to -1.35 & & Oerlemans and \\
\hline e.g. Storglaciären, Nigardsbreen & & $-0.7,-0.9$ & & others (1998) \\
\hline 37 glaciers & $\mathrm{TI}$ & -0.1 to -1.3 & & Braithwaite and \\
\hline e.g. Storglaciären & & -0.64 & & Zhang (1999) \\
\hline 61 glaciers & $\mathrm{TI}$ & -0.13 to -1.22 & & Braithwaite and \\
\hline $\begin{array}{l}\text { e.g. Devon Ice Cap, Storglaciären, Nigardsbreen, } \\
\text { Ålfotbreen }\end{array}$ & & $\begin{array}{l}-0.13,-0.56,-0.88 \\
-1.22\end{array}$ & $\begin{array}{l}+0.04,+0.18,+0.30 \\
+0.37\end{array}$ & others (2002) \\
\hline 9 Icelandic glaciers & $\mathrm{EB}$ & -0.49 to -0.80 & +0.27 to +0.35 & de Ruyter de Wildt \\
\hline $\begin{array}{l}\text { e.g. Dyngjujökull, Köldukvíslarjökull, W/E Brúarjökull, } \\
\text { Eyjabakkajökull, Tungnaárjökull }\end{array}$ & & $\begin{array}{l}-0.49,-0.50,-0.62 / \\
-0.73,-0.74,-0.77\end{array}$ & $\begin{array}{l}+0.28,+0.28,+0.29 / \\
+0.30,+0.27,+0.30\end{array}$ & and others (2003) \\
\hline 17 glaciers & $\mathrm{TI}$ & -0.2 to -1.5 & & $\begin{array}{l}\text { Schneeberger and } \\
\text { others (2003) }\end{array}$ \\
\hline Hellstugubreen, Nigardsbreen, Ålfotbreen & $\mathrm{EB}$ & $-0.72,-0.88,-1.11$ & & Oerlemans (1992) \\
\hline Hellstugubreen, Nigardsbreen, Ålfotbreen & $\mathrm{TI}$ & $-0.54,-0.60,-1.04$ & $+0.14,+0.23,+0.39$ & $\begin{array}{l}\text { Laumann and Reeh } \\
\text { (1993) }\end{array}$ \\
\hline austre Brøggerbreen and midre Lovénbreen & EB & -0.61 (average) & & $\begin{array}{l}\text { Fleming and others } \\
\text { (1997) }\end{array}$ \\
\hline $\begin{array}{l}\text { Nigardsbreen, Hardangerjøkulen, Storglaciären, } \\
\text { Hellstugubreen, Storbreen, Ålfotbreen }\end{array}$ & $\mathrm{TI}$ & $\begin{array}{l}-0.68,-0.71,-0.88 \\
-1.11,-1.13,-1.13\end{array}$ & $\begin{array}{l}+0.26,+0.26,+0.14 \\
+0.20,+0.07,+0.50\end{array}$ & $\begin{array}{l}\text { Nesje and others } \\
(2000)\end{array}$ \\
\hline $\begin{array}{l}\text { Rabots glaciär, Storglaciären, Storbreen, Hellstugubreen, } \\
\text { Langfjordjøkelen, Nigardsbreen, Austdalsbreen, } \\
\text { Rembesdalskåka, Gråsubreen, Hansebreen, Engabreen, } \\
\text { Ålfotbreen }\end{array}$ & $\mathrm{TI}$ & $\begin{array}{l}-0.30,-0.38,-0.42 \\
-0.48,-0.53,-0.59 \\
-0.62,-0.64,-0.73 \\
-0.86,-0.91,-1.01\end{array}$ & $\begin{array}{l}+0.16,+0.13,+0.15 \\
+0.13,+0.20,+0.24 \\
+0.32,+0.22,+0.12 \\
+0.36,+0.35,+0.41\end{array}$ & $\begin{array}{l}\text { Rasmussen and } \\
\text { Conway (2005) }\end{array}$ \\
\hline
\end{tabular}

in wetter or maritime climates tend to be more sensitive than subpolar or continental glaciers. Global mean static massbalance sensitivities of -0.39 and $-0.37 \mathrm{~m} \mathrm{a}^{-1} \mathrm{~K}^{-1}$ have been reported by Oerlemans (1993) and Dyurgerov and Meier (2000), respectively, the former estimate being based on modelling while the latter is derived from analysis of massbalance and temperature observations.

The purpose of our study is (1) to calibrate a mass-balance model with historic climate for 42 Arctic glaciers and ice caps, (2) to simulate the static mass-balance sensitivity to different hypothetical climate perturbations, (3) to analyze regional differences in mass-balance response, and (4) to approximate the effect of $\mathrm{a}+1 \mathrm{~K}$ warming on the contribution of Arctic glacier melt to sea-level rise. To be able to include a large number of glaciers, we use a simple model based on linear regression equations between measured glacier mass balance and observed daily air temperature and precipitation adopting a degree-day approach.

\section{DATABASE}

A total of 42 glaciers north of $60^{\circ} \mathrm{N}$ were included in the analysis. Only glaciers with data available for both winter and summer mass balances and a mass-balance record spanning $\geq 7$ years were considered. Data were retrieved from various sources such as web-based databases (e.g. Dyurgerov, 2002), literature (e.g. Björnsson and others, 1998, 2002) or direct contacts. The main sources for daily temperature and precipitation data were national meteorological institutes such as the Meteorological Service of Canada (Mekis and Hogg, 1999; Vincent and others, 2002) and the Meteorological Institute of the Netherlands (Klein Tank and others, 2002) as well as various websites. Daily climate data from a total of 45 climate stations are included in this study (Fig. 1). The distance between the glacier and the climate station varied considerably, ranging from a few hundred metres to several hundred kilometres. Missing data were interpolated using data from adjacent weather stations, and mass-balance years with climate data gaps exceeding 2 months were excluded.

A few mass-balance records span $>50$ years, with the longest, from Storglaciären, Sweden, dating back to 1945/ 46 , but the records unfortunately lack corresponding climate data for the entire period. The longest combined massbalance-climate dataset was found for Storbreen, Norway (45 years: 1957/58-2001/02). Six datasets from Canada and Norway included 40 years or more. Nine glaciers, most of them located in Iceland but some in Scandinavia, were calculated from only 7-9years, mostly due to short massbalance records (Table 2).

\section{METHOD}

The mass-balance model is based on daily temperature and precipitation data collected at climate stations near the glaciers, and separately measured summer and winter mass balances. Separate winter and summer mass balances instead of net mass balances enable a more distinct link to meteorological parameters (Dyurgerov and Meier, 1999), while daily instead of monthly climate data are used because the transition between summer and winter will shift under a changing climate (Oerlemans and Fortuin, 1992). The use of daily data 


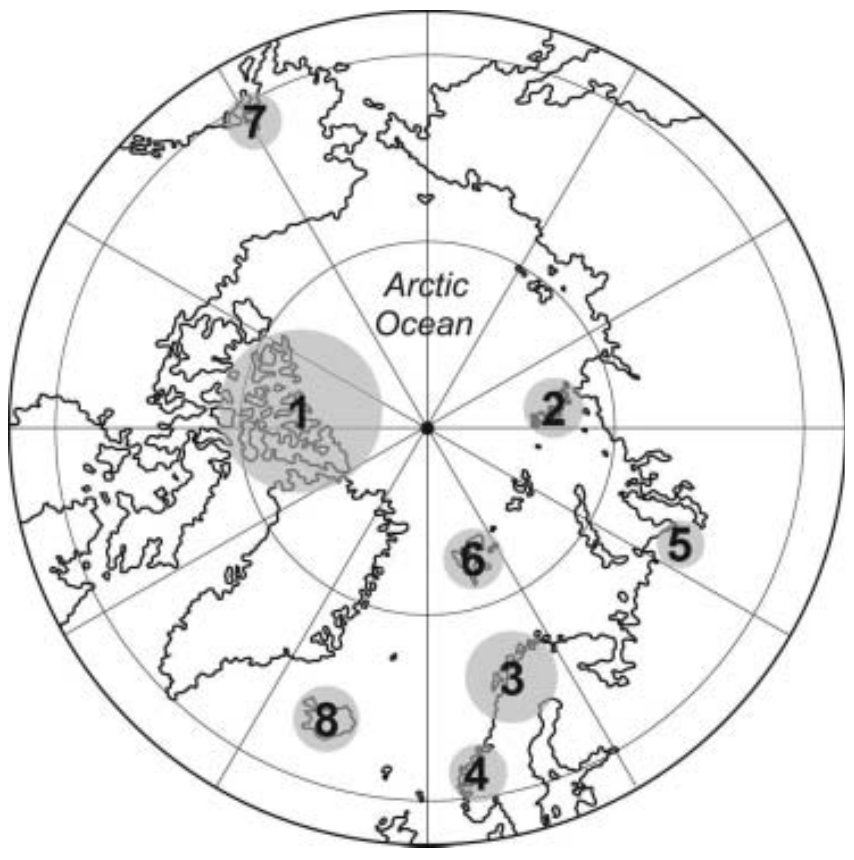

Fig. 1. Regions including the studied glaciers and ice caps: 1 Agassiz Ice Cap, Devon Ice Cap, Meighen Ice Cap, Melville South Ice Cap. 2 Vavilov ice dome. 3 Austre Okstindbreen, Engabreen, Langfjordjøkelen, Mårmaglaciären, Rabots glaciär, Riukojietna, Storglaciären, Storsteinfjellbreen, Tarfalaglaciären, Trollbergdalsbreen. 4 Ålfotbreen, Austdalsbreen, Gråbreen, Gråsubreen, Hansebreen, Hellstugubreen, Nigardsbreen, Rembesdalskåka, Storbreen. 5 IGAN, Obrucheva. 6 austre Brøggerbreen, Bertilbreen, Bogerbreen, Hansbreen, Kongsvegen, midre Lovénbreen. 7 Gulkana, Wolverine. 8 Blágnípujökull, Brúarjökull, Dyngjujökull, Eyjabakkajökull, Köldukvíslarjökull, Sátujökull, pjórsárjökull, Tungnaárjökull. Climate stations sorted after regions: 1 Alert, Clyde, Eureka, Mould Bay, Resolute, Sachs Harbour. 2 Hatanga, Ostrov Dikson. 3 Abisko, Alta Lufthavn, Bodø, Glomfjord, Katterjåkk, Kiruna Flygplats, Narvik, Nikkaluokta, Riksgränsen, Ritsem, Torneträsk, Tromsø. 4 Fannaråken, Fjærland-Skarestad, Fokstua, Sandane, Sognefjellet, Tafjord, Vågå-Klones, Vangsnes. 5 Berezovo, Hoseda-Hard, Mys Kamennyj. 6 Hornsund, Ny-Ålesund, Svalbard Lufthavn. 7 Cooper Lake Project, Gulkana Basin, Paxson, Wolverine Basin. 8 Akurnes, Fagurhólsmýri, Hjarðarnes, Hólar í Hornafirði, Hveravellir, Kirkjubæjarklaustur, Nautabú.

does not require the seasons to have defined lengths (cf. Oerlemans and Reichert, 2000) and has been found by Fleming and others (1997) to yield better results when comparing observed and modelled mass balances. Finally, future climate scenarios are often based on changes in temperature and precipitation (Jóhannesson and others, 1995).

To be able to involve a large number of glaciers, we adopt a simple model based on a degree-day approach (Hock, 2003). Glacier-averaged degree-day factors were obtained by regression analysis (Fig. 2). Linear regression equations between measured summer mass balances and the positive degree-day sum over the entire mass-balance year (Equation (1)), and between measured winter mass balances and the annual sum of daily precipitation, $P$, with air temperature at the glacier $T<0^{\circ} \mathrm{C}$ (Equation (2)), were established for each glacier. Summer mass balance, $b_{\mathrm{s}}$, and winter mass balance, $b_{\mathrm{w}}$, are then modelled by

$$
b_{\mathrm{s}}=\alpha_{\mathrm{s}} \sum_{t_{1}}^{t_{2}} a T+\beta_{\mathrm{s}}\left\{\begin{array}{l}
a=1, T>0 \\
a=0, T \leq 0
\end{array}\right.
$$
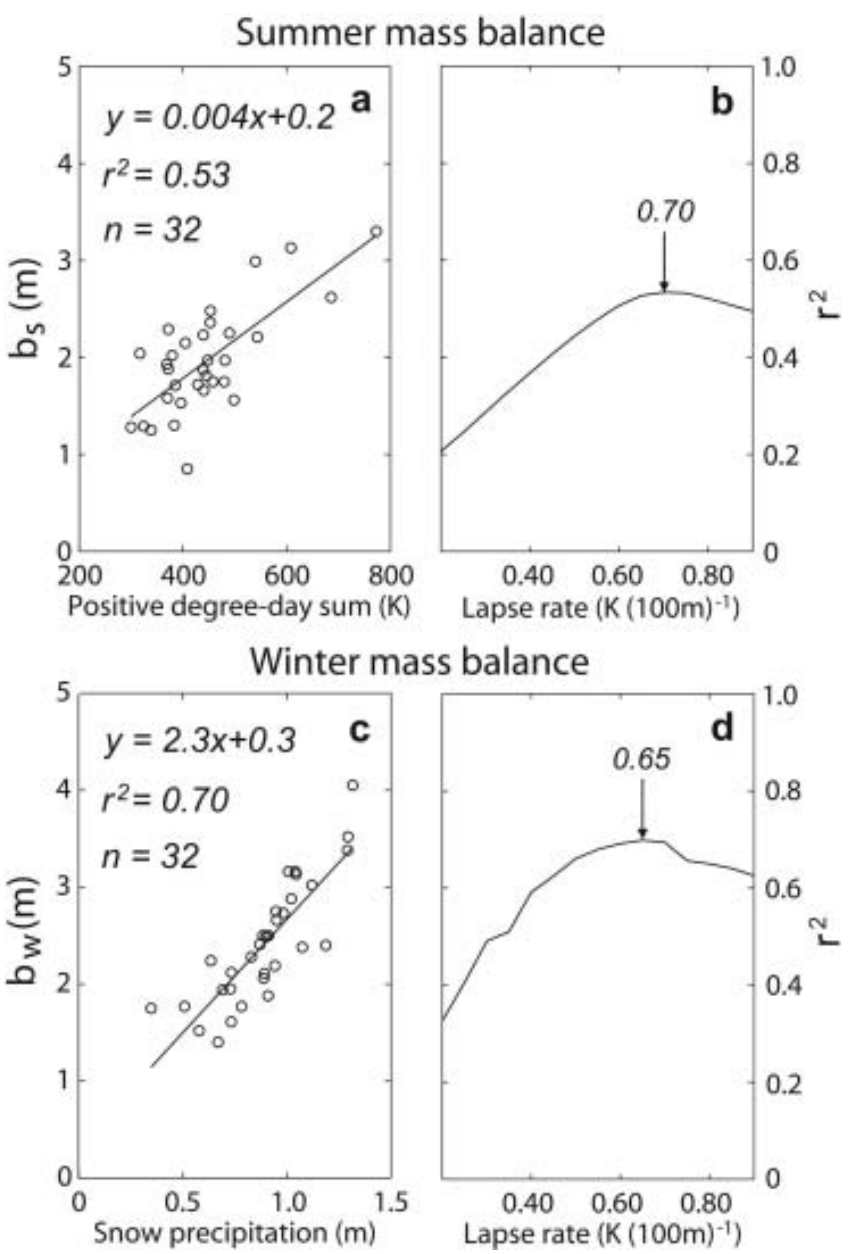

Fig. 2. Regression analysis for Nigardsbreen, Norway, over the period 1970/71-2001/02 using climate data from Sandane. Measured summer mass balance, $b_{\mathrm{s}}$, vs annual positive degree-day sum (a), and winter mass balance, $b_{\mathrm{w}}$, vs annual snow precipitation (c), including the number of mass-balance years considered, $n$, regression lines and equations based on the lapse rate yielding maximum $r^{2}$ as indicated by arrows in (b) and (d). A lapse rate of $0.70 \mathrm{~K}(100 \mathrm{~m})^{-1}$ was used for modelling both winter and summer balances in further analysis.

$$
b_{\mathrm{w}}=\alpha_{\mathrm{w}} \sum_{t_{1}}^{t_{2}} a P+\beta_{\mathrm{w}}\left\{\begin{array}{l}
a=1, T<0 \\
a=0, T \geq 0
\end{array}\right.
$$

where $\alpha$ and $\beta$ are regression coefficients, $\alpha_{\mathrm{s}}$ corresponding to the degree-day factor. Strictly speaking, the obtained mass balances $b_{\mathrm{s}}$ and $b_{\mathrm{w}}$ refer to total ablation and total accumulation respectively. $T$ and $P$ were integrated between 1 October $\left(t_{1}\right)$ and 30 September $\left(t_{2}\right)$, thus defining a massbalance year according to Dyurgerov (2002). Ohmura and others (1992) suggest that a glacier's climate is best represented by the climate at the equilibrium-line altitude. Hence, measured daily air temperatures were extrapolated from the altitude of the climate station to the altitude of the mean equilibrium line of each glacier, assuming a fictitious constant lapse rate. The lapse rate for each glacier was chosen to yield highest correlation coefficients in the linear regression (Fig. 2). In most cases, similar lapse rates were achieved for the summer and winter mass balances, and from the results one lapse rate per glacier was selected for further analysis. 
Table 2. Static sensitivity of mass balance $\left(\mathrm{m} \mathrm{a}^{-1}\right)$ to a $+1 \mathrm{~K}$ temperature increase $(T)$ or a $+10 \%$ precipitation increase $(P)$ for 42 glaciers north of $60^{\circ} \mathrm{N}$, continentality index $(\mathrm{Cl})$ for each climate station and the number of mass-balance years considered $(n)$, explained variance $\left(r^{2}\right)$ for summer mass balance $\left(b_{\mathrm{s}}\right)$ regression and winter mass-balance $\left(b_{\mathrm{w}}\right)$ regression. The glaciers are sorted by region $1-8$ (Fig. 1$)$ and subsorted within each region by increasing summer mass-balance sensitivity

\begin{tabular}{|c|c|c|c|c|c|c|c|c|c|c|}
\hline \multirow[t]{3}{*}{ Region } & \multirow[t]{3}{*}{ Glacier } & \multirow[t]{3}{*}{ Climate station } & \multirow[t]{3}{*}{$\mathrm{Cl}$} & \multirow[t]{3}{*}{$n$} & \multirow[t]{2}{*}{ Lapse rate } & \multicolumn{2}{|c|}{$r^{2}$} & \multicolumn{2}{|c|}{$\begin{array}{c}\text { Net mass-balance } \\
\text { sensitivity }\end{array}$} & \multirow{3}{*}{$\begin{array}{l}\text { Summer mass- } \\
\text { balance sensitivity } \\
\qquad \begin{array}{c}T+1 \mathrm{~K} \\
\mathrm{~m} \mathrm{a}^{-1}\end{array}\end{array}$} \\
\hline & & & & & & $b_{\mathrm{s}}$ & $b_{\mathrm{w}}$ & $T+1 \mathrm{~K}$ & $P+10 \%$ & \\
\hline & & & & & $\mathrm{K}(100 \mathrm{~m})^{-1}$ & & & $\mathrm{ma}^{-1}$ & $\mathrm{ma}^{-1}$ & \\
\hline \multirow[t]{3}{*}{1} & Devon Ice Cap & Clyde & 37 & 41 & 0.45 & 0.49 & $<0.15$ & - & - & -0.08 \\
\hline & Melville South Ice Cap & Mould Bay & 40 & 38 & 0.15 & 0.39 & $<0.15$ & - & - & -0.18 \\
\hline & Meighen Ice Cap & Eureka & 46 & 42 & 0.65 & 0.63 & $<0.15$ & - & - & -0.20 \\
\hline 2 & Vavilov ice dome & Hatanga & 49 & 10 & 1.50 & 0.43 & 0.46 & -0.20 & +0.03 & -0.18 \\
\hline \multirow[t]{9}{*}{3} & Mårmaglaciären & Abisko & 23 & 13 & 0.75 & 0.72 & 0.36 & -0.32 & +0.07 & -0.25 \\
\hline & Riukojietna & Narvik & 18 & 14 & 1.00 & 0.38 & 0.59 & -0.31 & +0.13 & -0.27 \\
\hline & Rabots glaciär & Ritsem & 23 & 17 & 0.80 & 0.69 & 0.69 & -0.39 & +0.14 & -0.32 \\
\hline & Storsteinfjellbreen & Riksgränsen & 22 & 10 & 0.60 & 0.49 & 0.47 & -0.44 & +0.12 & -0.36 \\
\hline & Storglaciären & Ritsem & 23 & 19 & 0.80 & 0.87 & 0.65 & -0.46 & +0.15 & -0.37 \\
\hline & Engabreen & Glomfjord & 15 & 33 & 0.75 & 0.64 & 0.79 & -0.99 & +0.32 & -0.66 \\
\hline & Tarfalaglaciären & Ritsem & 23 & 9 & 1.20 & 0.70 & 0.84 & -0.85 & +0.28 & -0.72 \\
\hline & Trollbergdalsbreen & Glomfjord & 15 & 10 & 0.75 & 0.60 & 0.70 & -1.05 & +0.22 & -0.78 \\
\hline & Langfjordjøkelen & Tromsø & 16 & 11 & 0.70 & 0.73 & 0.68 & -1.05 & +0.19 & -0.88 \\
\hline \multirow[t]{9}{*}{4} & Gråbreen & Vangsnes & 16 & 8 & 0.85 & 0.29 & 0.73 & -0.57 & +0.31 & -0.31 \\
\hline & Gråsubreen & Fokstua & 21 & 40 & 0.85 & 0.80 & 0.31 & -0.47 & +0.08 & -0.41 \\
\hline & Hellstugubreen & Fokstua & 21 & 40 & 0.75 & 0.79 & 0.33 & -0.58 & +0.07 & -0.50 \\
\hline & Nigardsbreen & Sandane & 17 & 32 & 0.70 & 0.53 & 0.69 & -0.66 & +0.22 & -0.52 \\
\hline & Storbreen & Fokstua & 21 & 45 & 0.65 & 0.81 & 0.48 & -0.65 & +0.12 & -0.54 \\
\hline & Rembesdalskåka & Fjærland-Skarestad & 19 & 40 & 0.80 & 0.68 & 0.70 & -0.66 & +0.28 & -0.55 \\
\hline & Ålfotbreen & Sandane & 17 & 32 & 0.65 & 0.58 & 0.80 & -1.25 & +0.36 & -0.84 \\
\hline & Austdalsbreen & Fjærland-Skarestad & 18 & 15 & 0.55 & 0.84 & 0.89 & -1.04 & +0.22 & -0.89 \\
\hline & Hansebreen & Fjærland-Skarestad & 19 & 17 & 0.60 & 0.74 & 0.85 & -1.15 & +0.25 & -0.97 \\
\hline \multirow[t]{2}{*}{5} & IGAN & Mys Kamennyj & 39 & 22 & 0.85 & 0.45 & $<0.15$ & - & - & -0.40 \\
\hline & Obrucheva & Mys Kamennyj & 39 & 22 & 0.85 & 0.53 & $<0.15$ & - & - & -0.47 \\
\hline \multirow{4}{*}{6} & Hansbreen & Svalbard Lufthavn & 23 & 12 & 0.95 & 0.89 & $<0.15$ & - & - & -0.53 \\
\hline & midre Lovénbreen & Ny-Ålesund & 22 & 23 & 0.90 & 0.76 & $<0.15$ & - & - & -0.56 \\
\hline & Bertilbreen & Svalbard Lufthavn & 25 & 10 & 0.45 & 0.80 & $<0.15$ & - & - & -0.63 \\
\hline & Bogerbreen & Ny-Ålesund & 22 & 10 & 0.50 & 0.82 & 0.30 & -0.93 & +0.04 & -0.90 \\
\hline \multirow[t]{2}{*}{7} & Gulkana & Paxson & 31 & 20 & 0.70 & 0.71 & 0.54 & -0.65 & +0.04 & -0.62 \\
\hline & Wolverine & Wolverine Basin & 18 & 32 & 0.60 & 0.58 & 0.58 & -0.84 & +0.23 & -0.67 \\
\hline \multirow[t]{8}{*}{8} & Blágnípujökull & Hveravellir & 16 & 9 & 0.80 & 0.93 & 0.49 & -0.78 & +0.06 & -0.75 \\
\hline & Köldukvíslarjökull & Kirkjubæjarklaustur & 13 & 9 & 0.65 & 0.45 & 0.60 & -0.93 & +0.19 & -0.80 \\
\hline & pjórsárjökull & Hveravellir & 16 & 9 & 0.60 & 0.90 & 0.61 & -0.98 & +0.11 & -0.89 \\
\hline & Sátujökull & Kirkjubæjarklaustur & 13 & 12 & 0.75 & 0.82 & 0.41 & -1.33 & +0.10 & -1.24 \\
\hline & Tungnaárjökull & Kirkjubæjarklaustur & 13 & 8 & 0.55 & 0.62 & 0.55 & -1.56 & +0.24 & -1.25 \\
\hline & Eyjabakkajökull & Fagurhólsmýri & 11 & 11 & 0.75 & 0.44 & 0.41 & -1.76 & +0.34 & -1.36 \\
\hline & Brúarjökull & Fagurhólsmýri & 11 & 9 & 0.70 & 0.35 & 0.49 & -1.67 & +0.16 & -1.49 \\
\hline & Dyngjujökull & Fagurhólsmýri & 11 & 7 & 0.75 & 0.69 & 0.83 & -2.01 & +0.18 & -1.75 \\
\hline
\end{tabular}

All 42 Arctic glaciers were analyzed using climate data from all climate stations near the glaciers for which the required data could be retrieved. In total, the regression analysis resulted in roughly 250 unique correlations between summer mass balance and the sum of positive degree-days, and between winter mass balance and annual snow precipitation. For each glacier, the regression based on data from the climate station yielding the best overall correlation for both winter and summer mass balances was used for further analysis. If a similar correlation was obtained for several stations, the climate station closer to the glacier or considered to be more representative, based on local expertise, was preferred.
Following other studies (Table 1), we calculated the static mass-balance sensitivity for each glacier. We use the term static following previous work (Table 1), altough some dynamic effects are indirectly incorporated since the model is calibated against mass-balance data that generally are integrated over the evolving glacier area (Elsberg and others, 2001), thus including effects of geometry changes on mass balance. We chose a climate perturbation ranging from +0 to $+4 \mathrm{~K}$ for temperature and +0 to $+40 \%$ for precipitation, but we focus on the results for $\mathrm{a}+1 \mathrm{~K}$ temperature and $\mathrm{a}$ $+10 \%$ precipitation change. These changes were uniformly applied to the measured climate-data records. When temperature was increased, precipitation was assumed 
unchanged and vice versa. The advantage of choosing such a hypothetical climate perturbation throughout the year is that it enables us to compare different models and sensitivity results using different methods for the same glaciers (cf. Table 1). Such uniform changes throughout the year are neither expected nor the only ones that may occur, but they act as a suitable standard (Braithwaite and Zhang, 1999) for comparing different glaciers and models.

To investigate sensitivities with respect to the climatic setting (continental/maritime), we quantified the degree of continentality of each glacier's location by a continentality index $(\mathrm{Cl})$ following Holmlund and Schneider (1997). The Cl is defined as the temperature amplitude during a massbalance year and is calculated from the difference in mean temperature between the coldest month and the warmest month. Large temperature amplitudes are associated with high-pressure systems and dry conditions and indicate continental conditions. Higher precipitation due to lowpressure systems is associated with smaller temperature amplitudes and generally milder climate, indicating that the $\mathrm{Cl}$ is connected to both temperature and precipitation. Following this approach, we calculated the $\mathrm{Cl}$ for each climate station (Table 2).

\section{RESULTS AND DISCUSSION}

\section{Model performance}

Table 2 indicates a large range of correlation coefficients in the regression analysis, at least partially resulting from the simplification of reality in our model by only including temperature and precipitation data in the mass-balance modelling. Highest correlation for the summer mass balance is found for Blágnípujökull, Iceland, where $93 \%$ of the variation can be explained by the positive degree-day sum derived from temperature data at Hveravellir. For the winter mass balance, the highest value $(89 \%)$ was obtained for Austdalsbreen, Norway, using the temperature and precipitation data at Fjærland-Skarestad, while most investigated glaciers in Canada, Svalbard and Russia showed no or very weak correlation. In the latter cases, the distance between the glacier and the location of available climate data tended to be large, reaching hundreds of kilometres, so the climate data are probably less representative for the climate conditions on the glacier. Generally, higher correlation was found for the summer mass balance than for the winter mass balance, which is attributed to the large spatial variability of precipitation compared to generally far more homogeneous spatial variability of temperature. Surprisingly, however, for some glaciers equal or better correlations were found for climate stations located farther away from the glacier. This may be due to small-scale climate heterogeneity, as typically found in mountain regions, in addition to problems with data quality since weather stations close to the glaciers are often less accessible and thus less frequently serviced. For instance, for the summer mass balance at Gulkana, Alaska, USA, better results were obtained using the data from the climate station Paxson, $25 \mathrm{~km}$ from the glacier, than using the data collected at the edge of the glacier. On Storglaciären, Sweden, using the temperature data from Ritsem, $>60 \mathrm{~km}$ away, yielded similar results to those using the data from Tarfala Research Station just $1 \mathrm{~km}$ from the glacier. Clearly, proximity between glacier and climate station does not necessarily yield the best results.
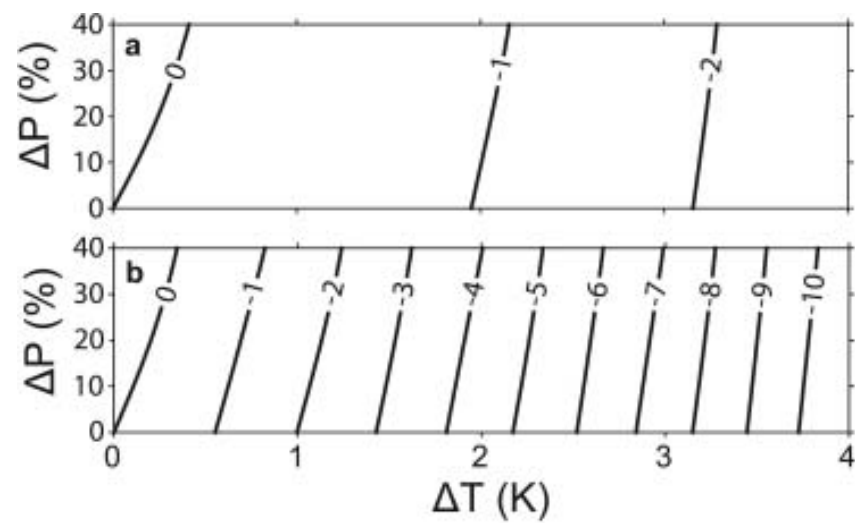

Fig. 3. Mass-balance change $\left(\mathrm{ma}^{-1}\right)$ to different hypothetical temperature increase $(\Delta T)$ and precipitation increase $(\Delta P)$ for Kongsvegen, Svalbard (a), and Dyngjujökull, Iceland (b).

The tuned lapse rates varied from 0.10 to $1.5 \mathrm{~K}(100 \mathrm{~m})^{-1}$ (Table 2), with low values for, for example, Agassiz Ice Cap, Canada, and high values for, for example, Vavilov ice dome, Severnaya Zemlya. Tuned lapse rates exceeding $1.0 \mathrm{~K}(100 \mathrm{~m})^{-1}$ may result from horizontal temperature gradients caused by large distances between glacier and climate station or other local effects. Hence, the tuned fictitious lapse rates include both horizontal and elevationdependent air-temperature variations.

\section{Mass-balance sensitivity}

The net mass-balance sensitivity to $\mathrm{a}+1 \mathrm{~K}$ temperature increase ranged from -0.2 to $-2.0 \mathrm{~m} \mathrm{a}^{-1}$ (Table 2). The assumed increase in precipitation by $+10 \%$ enhances mass balance by $<+0.1$ to $+0.4 \mathrm{~m} \mathrm{a}^{-1}$, and thus, on average, offsets the effect of the $+1 \mathrm{~K}$ temperature increase by approximately $20 \%$. The net mass-balance sensitivity was only calculated for 32 of the 42 glaciers due to very low correlation coefficients $\left(r^{2}<0.15\right)$ between winter mass balance and annual snow precipitation for some investigated glaciers. For glaciers with $r^{2}<0.15$ the mass-balance sensitivities were only computed for the summer mass balance assuming a $+1 \mathrm{~K}$ warming (Table 2). Results ranged from $-0.1 \mathrm{~m} \mathrm{a}^{-1}$ for Devon Ice Cap, Canada, to $-1.75 \mathrm{~m} \mathrm{a}^{-1}$ for Dyngjujökull, Iceland. Extremely high sensitivities were found for most Icelandic glaciers, especially at Vatnajökull, considerably exceeding the range of values previously reported for any other glacier in the world (Tables 1 and 2).

Our results for individual glaciers generally agree well with those obtained in previous studies (Tables 1 and 2), although for some glaciers the sensitivities deviate by up to roughly $0.25 \mathrm{~m} \mathrm{a}^{-1}$. Although the sample size is low, it seems that best agreement is found with results also based on temperature-index methods. Braithwaite and Zhang (1999) found uncertainties for static mass-balance sensitivities of about $\pm 0.1 \mathrm{~m} \mathrm{a}^{-1} \mathrm{~K}^{-1}$, although it is uncertain if this value also applies to other model formulations.

Figure 3 illustrates examples for low and high massbalance changes resulting from temperature and precipitation perturbations of 0 to $+4 \mathrm{~K}$ and 0 to $+40 \%$, respectively. Considering, for example, a temperature increase by $3 \mathrm{~K}$, Kongsvegen's mass-balance change exceeds $-2 \mathrm{~m} \mathrm{a}^{-1}$, while the corresponding value for Dyngjujökull exceeds $-8 \mathrm{ma}^{-1}$. Although for larger perturbations static sensitivities become increasingly meaningless, since dynamic effects are not 

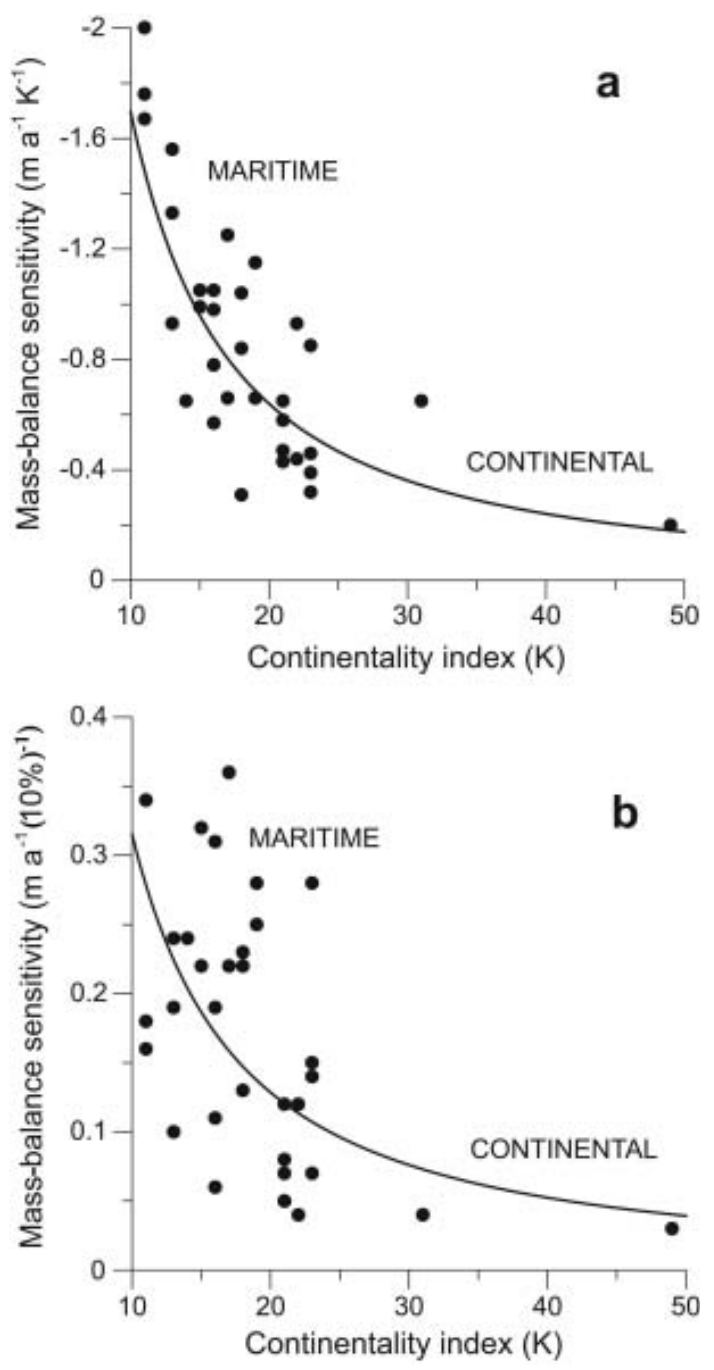

Fig. 4. Static net mass-balance sensitivity vs $\mathrm{Cl}(\mathrm{K})$ for 32 glaciers north of $60^{\circ} \mathrm{N}$ : (a) to a temperature change by $+1 \mathrm{~K}$ (inverted scale $y$ axis, best fit: $\left.y=-39.87 x^{-1.37}\right)$; and (b) to a precipitation change by $+10 \%$ (best fit: $y=7.38 x^{-1.37}$ ).

included and the sensitivities for larger perturbations follow a non-linear behaviour, the difference clearly reveals the different glacier response in different climate regimes, Kongsvegen being located in a more continental, and Dyngjujökull in a more maritime, setting.

\section{Degree of continentality}

Figure 4 illustrates that a glacier located in a maritime climate with smaller annual temperature amplitude tends to have a higher sensitivity than a glacier located in a continental climate with larger temperature amplitude. These findings are in agreement with previous studies (e.g. Oerlemans and Fortuin, 1992; Laumann and Reeh, 1993; Braithwaite and Zhang, 1999; Braithwaite and others, 2002; Schneeberger and others, 2003). The variation in massbalance sensitivity to a temperature increase can be explained to $61 \%$ (Fig. 4a) by the degree of continentality as expressed by the continentality index. The corresponding value for a precipitation increase is only $37 \%$ (Fig. 4b). Excluding the outlier Vavilov ice dome $(\mathrm{Cl}=49)$ from the analysis, these values are reduced to $51 \%$ and $25 \%$, respectively. A larger than average relationship between

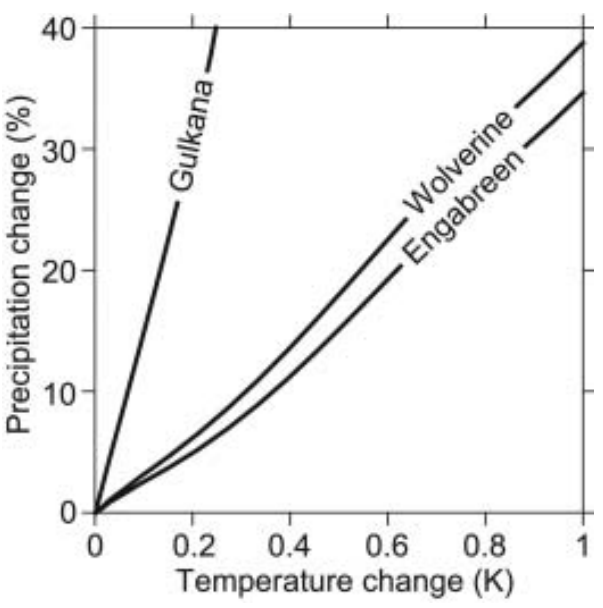

Fig. 5. Zero net mass-balance change $\left(\mathrm{ma}^{-1}\right)$ as a function of precipitation increase $(\%)$ and temperature increase $(\mathrm{K})$ for Gulkana, Alaska, Wolverine, Alaska, and Engabreen, Norway.

the variation in mass-balance sensitivity and continentality index is found in Iceland for both summer mass balance $(77 \%)$ and winter mass balance (53\%). Higher sensitivities for maritime than for continental glaciers can be attributed to differences in annual temperature amplitudes. Due to lower annual temperature amplitudes, the fraction of precipitation that falls as rain instead of snow will increase to a greater extent than in climates with large temperature amplitudes (Oerlemans and Fortuin, 1992).

Different behaviour for maritime and continental settings is also evident from Figure 5, visualizing different slopes of the zero net mass-balance change as a function of assumed temperature and precipitation changes. Continental Gulkana needs a roughly $30 \%$ increase in precipitation to compensate for a temperature increase of $+0.2 \mathrm{~K}$, whereas for maritime Wolverine, Alaska, located $370 \mathrm{~km}$ away, a $<5 \%$ increase in precipitation is sufficient not to change the mass balance. Engabreen, Norway, also located in a strongly maritime environment, similarly to Wolverine shows a course of zero net mass-balance change. In general, much higher percentage increases in precipitation are needed for continental than for maritime glaciers in order to balance the effects of a temperature increase.

\section{Contribution to sea level}

Following Oerlemans and others (2005), we estimated the contribution of Arctic glaciers to sea-level rise for a uniform $+1 \mathrm{~K}$ warming. For each region, the mass-balance sensitivities of all glaciers considered were averaged using areaweighted means. The mean sensitivities were then multiplied by total ice area coverage for each region, and divided by total area of the world ocean $\left(362 \times 10^{6} \mathrm{~km}^{2}\right)$. The method is rough since it uses regional sensitivities based on only a few glaciers that are assumed to be representative of the entire region. We excluded the Greenland ice sheet, the Canadian Arctic, Zemlya Frantsa Iosifa, the Ural Mountains and Novaya Zemlya due to lack of sufficient mass-balance and climate data or due to insufficient correlation coefficients (Table 2). Results are presented in Table 3. The total contribution of glacier melt for $\mathrm{a}+1 \mathrm{~K}$ warming from Severnaya Zemlya, Norway/Sweden, Svalbard, Alaska and Iceland amounts to $0.26 \mathrm{~mm} \mathrm{a}^{-1}$ and hence exceeds the value of $0.19 \mathrm{~mm} \mathrm{a}^{-1}$ obtained by Oerlemans and others 
Table 3. Contribution of glacier melt from various regions north of $60^{\circ} \mathrm{N}$ to sea-level rise in response to a $+1 \mathrm{~K}$ warming, compared to the results by Oerlemans and others (2005)

\begin{tabular}{|c|c|c|c|c|}
\hline & \multirow{3}{*}{$\begin{array}{c}\text { Glacier area } \\
\text { (Oerlemans and others, 2005) } \\
10^{3} \mathrm{~km}^{2}\end{array}$} & \multirow{3}{*}{$\begin{array}{l}\text { Mean static mass-balance } \\
\text { sensitivity } \\
\qquad \mathrm{m} \mathrm{a}^{-1}\end{array}$} & \multicolumn{2}{|c|}{ Contribution to sea level } \\
\hline & & & This study & $\begin{array}{l}\text { Oerlemans and others } \\
\text { (2005) }\end{array}$ \\
\hline & & & $10^{-3} \mathrm{~mm} \mathrm{a}^{-1}$ & $10^{-3} \mathrm{~mm} \mathrm{a}^{-1}$ \\
\hline Severnaya Zemlya & 18.3 & -0.200 & 10 & 18 \\
\hline Norway/Sweden & 3.1 & -0.744 & 6 & 5 \\
\hline Svalbard & 36.6 & -0.449 & 45 & 25 \\
\hline Alaska & 75 & -0.740 & 153 & 120 \\
\hline Iceland & 10.9 & -1.630 & 49 & 25 \\
\hline Total & & & 263 & 193 \\
\hline
\end{tabular}

(2005) for the same area. Using our results, but adopting the sensitivities obtained by Oerlemans and others (2005) for the areas that had to be excluded from our analysis, yields an estimate of the total contribution to sea level from Arctic glaciers and ice caps of about $\sim 0.6 \mathrm{~mm} \mathrm{a}^{-1}$, compared to $0.53 \mathrm{~mm} \mathrm{a}^{-1}$ found by Oerlemans and others (2005).

\section{CONCLUSIONS}

We used a simple mass-balance model established from linear regression between measured summer glacier mass balance and observed daily air temperature, and between winter glacier mass balance and snow precipitation. The model was applied to 42 glaciers and ice caps north of $60^{\circ} \mathrm{N}$ to compute the static mass-balance sensitivity to different hypothetical climate perturbations. Our main findings are:

The sensitivities of the glacier net mass balance of 32 glaciers and ice caps north of $60^{\circ} \mathrm{N}$ in response to a hypothetical $+1 \mathrm{~K}$ temperature increase show a large variation, ranging from -0.2 to $-2.0 \mathrm{~m} \mathrm{a}^{-1}$. The range is larger than reported in previous studies for glaciers worldwide $\left(-0.1\right.$ to $\left.-1.35 \mathrm{~m} \mathrm{a}^{-1}\right)$. The sensitivities of the summer mass balance for 42 Arctic glaciers to a temperature change of $+1 \mathrm{~K}$ ranged from -0.1 to $-1.8 \mathrm{ma}^{-1}$. The highest sensitivities were found for glaciers in Iceland.

On average, an assumed increase in precipitation of $10 \%$ tends to offset the effect of a temperature change of $+1 \mathrm{~K}$ by approximately $20 \%\left(<+0.1\right.$ to $\left.+0.4 \mathrm{~m} \mathrm{a}^{-1}\right)$.

The variation in mass-balance sensitivities could at least partially be attributed to the climate setting where the glacier is located. Sensitivities tend to increase as climate conditions become more maritime, as expressed by the $\mathrm{Cl}$.

The estimated contribution from Arctic glaciers and ice caps to sea-level rise in response to a $+1 \mathrm{~K}$ warming is $\sim 0.6 \mathrm{~mm} \mathrm{a}^{-1}$.

\section{ACKNOWLEDGEMENTS}

We gratefully acknowledge the large number of organizations and individuals that provided us with the necessary input data. Complementary useful information was provided by A. Arendt, H. Björnsson, K. Braun, S. Debatin,
M. Dyurgerov, G. Gísladóttir, P. Glowacki, S. Guðmundsson, T. Jóhannesson, M. Johansson, R. Koerner, B. Kjøllmoen, J. Kohler, Y. Kramer, E. Mekis, I.M. Nordin, M. Skogh and L. Vincent. Additional climate data were obtained from the All-Russian Research Institute of Hydrometeorological Information, the Swedish Meteorological and Hydrological Institute and the United States Geological Survey. We also owe a debt to everyone who has measured mass-balance and climate data during the past century. Funding was received from the C.F. Liljevalch J:ors fund, Axel Lagrelius fund, Rhodins fund and the Swedish Research Council. This study is a contribution to the CE (Climate and Energy) project funded by Nordic Energy Research (NEFP). Comments by R. Braithwaite, P. Jansson, T. Jóhannesson, M. Hansson and A. Rasmussen helped to improve the manuscript.

\section{REFERENCES}

Arctic Climate Impact Assessment (ACIA). 2005. Impacts of a warming Arctic. Cambridge, Cambridge University Press.

Arendt, A.A., K.A. Echelmeyer, W.D. Harrison, C.S. Lingle and V.B. Valentine. 2002. Rapid wastage of Alaska glaciers and their contribution to rising sea level. Science, 297(5580), 382-386.

Björnsson, H., F. Pálsson, M.T. Gudmundsson and H.H. Haraldsson. 1998. Mass balance of western and northern Vatnajökull, Iceland, 1991-1995. Jökull, 45, 35-58.

Björnsson, H., F. Pálsson and H. Haraldsson. 2002. Mass balance of Vatnajökull (1991-2001) and Langjökull (1996-2001), Iceland. Jökull, 51, 75-78.

Braithwaite, R.J. and Y. Zhang. 1999. Modelling changes in glacier mass balance that may occur as a result of climate changes. Geogr. Ann., 81A(4), 489-496.

Braithwaite, R.J., Y. Zhang and S.C.B. Raper. 2002. Temperature sensitivity of the mass balance of mountain glaciers and ice caps as a climatological characteristic. Z. Gletscherkd. Glazialgeol., 38(1), 35-61.

Church, J.A. and 7 others. 2001. Changes in sea level. In Houghton, J.T. and 7 others, eds. Climate change 2001: the scientific basis. Contribution of Working Group I to the Third Assessment Report of the Intergovernmental Panel on Climate Change. Cambridge, etc., Cambridge University Press, 639-693.

De Ruyter de Wildt, M., J Oerlemans and H Björnsson. 2003. A calibrated mass balance model for Vatnajökull, Iceland. Jökull, 52, 1-20.

Dowdeswell, J.A. and J.O. Hagen. 2004. Arctic glaciers and ice caps. In Bamber, J.L. and A.J. Payne, eds. Mass balance of the cryosphere. Cambridge, Cambridge University Press, 527-557. 
Dowdeswell, J.A. and 10 others. 1997. The mass balance of circum-Arctic glaciers and recent climate change. Quat. Res., $\mathbf{4 8}(1), 1-14$

Dyurgerov, M. 2002. Glacier mass balance and regime: data of measurements and analysis. INSTAAR Occasional Paper 55.

Dyurgerov, M.B. and M.F. Meier. 1997. Mass balance of mountain and subpolar glaciers: a new global assessment for 1961-1990. Arct. Alp. Res., 29(4), 379-391.

Dyurgerov, M.B. and M.F. Meier. 1999. Analysis of winter and summer glacier mass balances. Geogr. Ann., 81A(4), 541-554.

Dyurgerov, M.B. and M.F. Meier. 2000. Twentieth century climate change: evidence from small glaciers. National Academy of Sciences Proceedings (PNAS), 97(4), 1406-1411.

Elsberg, D.H., W.H. Harrison, K.A. Echelmeyer and R.M. Krimmel. 2001 Quantifying the effects of climate and surface change on glacier mass balance. J. Glaciol., 47(159), 649-658.

Fleming, K.M., J.A. Dowdeswell and J. Oerlemans. 1997. Modelling the mass balance of northwest Spitsbergen glaciers and responses to climate change. Ann. Glaciol., 24, 203-210.

Hock, R. 2003. Temperature index melt modelling in mountain areas. J. Hydrol., 282(1-4), 104-115.

Holmlund, P. and T. Schneider. 1997. The effect of continentality on glacier response and mass balance. Ann. Glaciol., 24, 272-276.

Jóhannesson, T. 1997. The response of two Icelandic glaciers to climatic warming computed with a degree-day glacier massbalance model coupled to a dynamic glacier model. J. Glaciol., 43(144), 321-327.

Jóhannesson, T., O. Sigurdsson, T. Laumann and M. Kennett. 1995. Degree-day glacier mass-balance modelling with applications to glaciers in Iceland, Norway and Greenland. J. Glaciol., 41(138), 345-358.

Klein Tank, A.M.G. and 37 others. 2002. Daily dataset of 20thcentury surface air temperature and precipitation series for the European Climate Assessment. Int. J. Climatol., 22(12), $1441-1453$.

Laumann, T. and N. Reeh. 1993. Sensitivity to climate change of the mass balance of glaciers in southern Norway. J. Glaciol., 39(133), 656-665.

Mekis, É. and W.D. Hogg. 1999. Rehabilitation and analysis of Canadian daily precipitation time series. Atmosphere-Ocean, 37(1), 53-85.
Nesje, A., Ø. Lie and S.O. Dahl. 2000. Is the North Atlantic Oscillation reflected in Scandinavian glacier mass balance records? J. Quat. Sci., 15(6), 587-601.

Oerlemans, J. 1992. Climate sensitivity of glaciers in southern Norway: application of an energy-balance model to Nigardsbreen, Hellstugubreen and Alfotbreen. J. Glaciol., 38(129), 223-232.

Oerlemans, J. 1993. Modelling of glacier mass balance. In Peltier, W.R., ed. Ice in the climate system. Berlin, etc., Springer-Verlag, 101-116. (NATO ASI Series I: Global Environmental Change 12.)

Oerlemans, J. and J.P.F. Fortuin. 1992. Sensitivity of glaciers and small ice caps to greenhouse warming. Science, 258(5079), $115-117$.

Oerlemans, J. and B.K. Reichert. 2000. Relating glacier mass balance to meteorological data by using a seasonal sensitivity characteristic. J. Glaciol., 46(152), 1-6.

Oerlemans, J. and 10 others. 1998. Modelling the response of glaciers to climate warming. Climate Dyn., 14(4), 267-274.

Oerlemans, J. and 8 others. 2005. Estimating the contribution from Arctic glaciers to sea-level change in the next 100 years. Ann. Glaciol., 42 (see paper in this volume).

Ohmura, A., P. Kasser and M. Funk. 1992. Climate at the equilibrium line of glaciers. J. Glaciol., 38(130), 397-411.

Przybylak, R. 2003. The climate of the Arctic. Dordrecht, etc., Kluwer Academic.

Rasmussen, L.A. and H. Conway. 2005. Influence of upper-air conditions on glaciers in Scandinavia. Ann. Glaciol., 42 (see paper in this volume)

Reichert, B.K., L. Bengtsson and J. Oerlemans. 2001. Midlatitude forcing mechanisms for glacier mass balance investigated using general circulation models. J. Climate, 14(17), 3767-3784.

Schneeberger, C., O. Albrecht, H. Blatter, M. Wild and R. Hock. 2001. Modelling the response of glaciers to a doubling in atmospheric $\mathrm{CO}_{2}$ : a case study of Storglaciären. Climate Dyn., 17(11), 825-834.

Schneeberger, C., H. Blatter, A. Abe-Ouchi and M. Wild. 2003. Modelling changes in the mass balance of glaciers of the northern hemisphere for a transient $2 \times \mathrm{CO}_{2}$ scenario. J. Hydrol., 282, 145-163.

Vincent, L.A., X. Zhang, B.R. Bonsal and W.D. Hogg. 2002. Homogenization of daily temperatures over Canada. J. Climate, 15(11), 1322-1334. 